\title{
Physico-Chemical Analysis of Protein Fortified Papaya Jam
}

\author{
Dimas Bayu Pinandoyo ${ }^{1}$, Saleem Siddiqui ${ }^{2}$, M.K. Garg $^{3}$ \\ ${ }^{1}$ Faculty of Science and Technology, Universitas Al Azhar Indonesia, Jl. Sisingamangaraja, RT 2/ RW 1, \\ Selong Kebayoran Baru, Kota Jakarta Selatan, DKI Jakarta 12110 \\ ${ }^{2}$ Centre of Food Science and Technology, CCS HAU, Hisar- 125004 \\ ${ }^{3}$ College of Agricultural Engineering and Technology, CCS Haryana Agricultural University, Hisar - 125004
}

Author for Correspondence/E-mail: bayu7322@gmail.com

\begin{abstract}
Vegetarian food products content less protein source compare to non-vegetarian. Protein fortification is one of the option can be chosen to fulfil protein needs of the vegetarian consumer. Papaya Jam was fortified with protein isolate from soy bean with amount of $5 \%$. The analysis of physico-chemical analysis was done using Association of Official Agricultural Chemist (AOAC) official methods of analysis. The physico-chemical analysis of protein fortified papaya jam showed that the product had 31.07 \pm 0.20 $\%$ moisture contents, $68.00 \pm 0.54 \%$ Total Soluble Solid, $0.49 \pm 0.02 \%$ of acidity, $3.27 \pm 0.52$ in $\mathbf{p H}, 31.30 \pm$ $0.10 \mathrm{mg} / 100 \mathrm{~g}$ ascorbic acid content, $53.60 \pm 0.18 \%$ total sugar amount, $33.60 \pm 0.78 \%$ reducing sugar, $2.81 \pm 0.08 \mathrm{mg} / 100$ total carotenoid, $0.540 .54 \pm 0.02 \mathrm{mg} / 100 \mathrm{~g}$ total phenol, and $5.43 \pm 0.06 \%$ dwb of crude protein content. The physico-chemical of protein fortified papaya jam found still in the range of jam standard standardized by FAO and previous research results for physico-chemical analysis of jam.ntuk naskah berbahasa Indonesia, abstrak ditulis dalam bahasa Indonesia dan bahasa Inggris.
\end{abstract}

Keywords - Physico-chemical, protein, fortification, papaya, jam

\section{INTRODUCTION}

$\mathrm{P}$ rotein is very important for human being. Mainly having structural dan functional role, protein playing a major impact in live being. Deficiency of protein may lead to severe weight lost, malfunction in growth, protein energy deficiency, and the most severe is kwashiorkor [1]. Vegetarian having difficulties in protein intake. Although finding protein source is not difficult for vegetarian Vegetarian protein source reported less efficient compared to animal based protein sourced since the vegetable source's lack of one or more of the essential amino acids [2]. Enriching protein content by fortification from other plant sources can be an effective approach to solve this problem.

Historically jams have originated as an early effort to preserve fruit for consumption in the off-season. Jams can be made from a large range of fruits. It can conveniently be used and is having high nutritional value. The fruits jams have very low levels of fatty acids. Fruit jams provide an affordable and convenient source of energy and carbohydrate. Today, jams have become so popular that they are a common 'ready-to- serve' breakfast item for most of the families. However, due to inherent poor protein content of fruits, fruit jams have very low protein levels.

The papaya plant (Carica papaya L.) is grown in every tropical and subtropical country and belongs to Caricaceae family. Papaya has excellent digestive and nutritive value, pleasant flavour, high palatability and abundance at moderate price. The fruit is known for its carotenoid content and retinol activity, to counteract vitamin A deficiency. Provitamin A carotenoids average $232 \mu \mathrm{g} \beta$-carotene and $594 \mu \mathrm{g} \beta$-cryptoxanthin/100 $\mathrm{g}$ and vitamin $\mathrm{A}$ ranged from 18 to $74 \mu \mathrm{g}$ RAE (retinol activity equivalents)/100 g. Lycopene content in the redfleshed varieties ranged from 1350-3674 $\mu \mathrm{g} / 100 \mathrm{~g}$ [3]. Its vitamin $C$ content is $\sim 50 \mathrm{mg} / 100 \mathrm{~g}$ [4]. Because of faster fruit softening consequent to ripening, and the recorded transportation losses up to $40 \%$, the fruit requires conversion into processed products, to ensure extended storage, for transportation, trade and consumption [5]. Juice, blended beverages, jam (including low calorie), jelly, dehydrated, osmo dried, fruit bar, candy, restructured and intermediate moisture and frozen products, etc. could be developed from the fresh fruit [6]. The pectin content of the fruit aids in jam preparation and easy setting. 
Physico-chemical is the physical and chemical characteristic of food. The physical and chemical characteristic of food playing the major rule in development of food industries. It consists of color, structure, rheology, water activity, acid and phenol content, $\mathrm{pH}$, sugar content, etc. $\mathrm{pH}$ and acidity, for example, may affect the mouthfeel, water content, and automatically affect the structure. Water activity can show the diffusion of water during processing that may affect the moisture content of final product. Moisture content further will affect the biological properties of food product, thus affect the shelf life of the product [5]. Understanding physico-chemical of food is very important to design development of issues and problem faced in food industry [7].

The majority of people in developing countries suffer from the deficiency of protein intake in their diets due to scarcity and high cost of animal or dairy based sources of protein. This problem demands consumption of plant based protein with low cost and good quality. Enriching jams' protein content by fortification from other plant sources can thus be an effective approach to improve its nutritional value.

\section{Protein Isolate and Concentrate}

Soy protein products (SPP) are food products produced by the reduction or removal from soyabeans of certain of the major non-protein constituents (water, oil, carbohydrates) in a manner to achieve a protein $(\mathrm{N} \times 6.25)$ content of $50 \%$ or more and less than $65 \%$ ( soy protein flour, SPF); $65 \%$ or more and less than $90 \%$ (soy protein concentrate, SPC); and $90 \%$ or more (soy protein isolate, SPI). The protein content is calculated on a dry weight basis excluding added vitamins, minerals, amino acids and food additives. It has to be clean, sound, mature, obtained from dry seeds essentially free from other seeds and foreign matter in accordance with Good Manufacturing Practice. Moisture content should not exceed 10\%, ash should not exceed $8 \%$ and crude fiber should not exceed than $5 \%$ (SPF); $6 \%$ (SPC); and $0.5 \%$ (SPI) on a dry weight basis. It shall be free from heavy metals and from micro-organisms in amounts which may represent a hazard to health, shall not contain substances originating from micro-organisms and other poisonous substances in amounts which may represent a hazard to health [8].

\section{Jams}

Jam means the product prepared from sound, ripe, fresh, dehydrated, frozen or previously packed fruits including fruit juices, fruit pulp, fruit juice concentrate or dry fruit by boiling its pieces or pulp or puree with nutritive sweeteners namely sugar, dextrose, invert sugar or liquid glucose to a suitable consistency. It may contain fruit pieces and any other ingredients suitable to the products, prepared from any of the suitable fruits (singly or in combination), have the flavour of the original fruits, and free from burnt or objectionable flavour and crystallization. Total soluble solids (w/w) shall not less than $65 \%$ and the product shall be manufactured from not less than 45 per cent by weight of original prepared fruit, exclusive of any added sugar or optional ingredients of finished product (in strawbery and raspbery should contain not less than $25 \%)$ [2].

\section{Protein Enriched Fruit Product}

Fruit product content very less protein product. The fortification and enrichment of food product have been done recently. In soy protein enriched peach fruit leather the limit of acceptability for protein was $2 \%$ and $3 \%$ enrichment was not acceptable [9]. In four month storage, TSS, acidity, and sugar were increased while protein content, fat, and ascorbic acid decreased. Guava nectar supplemented with soymilk had increased protein content as much as $2.6 \%$ to $5.34 \%$ at fresh preparation. T.S.S, pH, ascorbic acid, protein and total sugars content of the drink decreased during storage, while the acidity of the product increased rapidly after 60 days causing the off-odour [10] The use of soyabean processed flour to improve the nutritional quality of guava (Psidium gujava L.) jam giving the result that gel was softer when concentration of soyabean was higher. The satisfactory quality jam could not be prepared when amounts of the parts of soyabean exceeded 4 against 40 parts of guava in its recipe [11].

\section{METHOD}

\section{Design, Place and Time}

The research designed through 3 phases. First phase was the collection of papaya pulp. The second was preparation of papaya jam. The third phase was incorporation of protein isolate in to papaya jam.

For the papaya pulp preparation, the papaya fruits were washed thoroughly with clean running water and cut into slices with stainless steel knife. The slices were ground in a grinder for obtaining papaya pulp. Sodium benzoate @ $1 \mathrm{~g} / \mathrm{kg}$ pulp was mixed with the pulp. The pulp was then packed in polypropylene jars and stored in deep freezer. 
Papaya jam was prepared using the recipe below: $1 \mathrm{~kg}$ papaya pulp, $700 \mathrm{~g}$ sugar, $4 \mathrm{~g}$ citric acid and 2 g pectin.

Papaya pulp was added with soy protein isolate as much as 5\% per amount of papaya pulp. Sugar was added and cooked with constant stirring until thick consistency was formed. Citric acid was added in between and dissolved pectin was added after TSS reached $68 \%$. End point was judged by sheet test and measuring total soluble solids $(68 \%)$ using hand refractometer (58-92\%). The product was packed in $150 \mathrm{~g}$ capacity sterilized. The product was packed in $150 \mathrm{~g}$ capacity sterilized glass jars and stored. The treatments were replicated thrice in a completely randomized design.

The research was conducted in Center of Food Science and Technology, Chaudhary Charan Singh Haryana Agricultural University during winter, from January 2016 - Mei 2016.

\section{Sampling}

Ripe Papaya cv. Disco fruits and soy flour were procured from the local market, Hisar,Haryana, India for extracting pulp for making jam. The soy protein isolate was procured from Titan Biotech Ltd (India).

\section{Data Collection}

The physico-chemical properties was determined according to standard methods. The $\mathrm{pH}$ meter was calibrated by adjusting with buffers 4 and 7 solutions. The soluble solids of the fruit and jam calculated in ${ }^{\circ}$ Brix were determined using Abbey refractometer (Bausch and Lomb). Samples were placed on the sample holder of the refractometer that had been standardized to the zero mark with distilled water. The refractive index and ${ }^{\circ}$ Brix were read from the refractometer. $\mathrm{pH}$ was determined using $\mathrm{pH}$ meter (model BA 350 EDT instruments). Moisture content was analyzed using oven method. Acidity, Ascorbic Acid Content, Total Phenol, and Crude Protein was analyzed using AOAC (1990) [12]. Total and Reducing Sugar was analyzed using Hulme and Narain (1931) methods [2]. Total carotenoids were determined as per the procedure described [11]. Antioxidant activity was measured using 2,2-diphenyl- 1-picrylhydrazyl (DPPH) dye, as per the procedure described by Shimada et al., (1992) [13]. Non - Enzymatic Browning was recorded for fresh product and stored product. [14].

\section{Data Analysis}

The data in the present investigation were subjected to analysis of variance (ANOVA) techniques and analyzed according to 2-factorial completely randomized design (CRD). The critical difference value at 5 per cent level was used for making comparison among different treatments during three months storage period.

\section{RESULT AND DISCUSSION}

CODEX STAN 296 described that jam shall be of an appropriate gelled consistency, having normal colour and flavour appropriate to the type or kind of fruit ingredient used in the preparation of the mixture. By this meaning we also able to compare the physico-chemical characteristic of jam made some fruit with jam made with other fruit. This research show that the papaya jam fortified with soy protein isolate as much as $5 \%$ per part of the jam, having $31.07 \pm 0.20 \%$ moisture contents. Basic papaya jam having moisture content around $32.10 \%$ [5]. Fortified papaya jam with soy meal powder having moisture content $34.60 \pm 3.82 \%$ [2]. Sapodilla jam having moisture content around 28$40 \%$ [15] and it was considered as normal in jam. Moisture content will affect the water-solid interaction in jam. Furthermore if not controlled properly, it may affect the gelling characteristic of jam. In this research, the fortification of soya protein isolate proofed not affecting the moisture content of jam.

Total Soluble Solid (TSS) of fortified papaya jam was $68.00 \pm 0.54 \%$. Basic papaya jam's moisture was around $68 \%$ [15]. The Schumacer Center in their technical brief in practical action challenging poverty stated that the best TSS for jam is $68 \%$ since it will give best texture. If jam proceed with more than $68 \%$ in TSS, it will give crystal and grittiness texture after packaging. Same standard also used by FAO. Maximum amount of TSS for jam is 70\% [16].

Acidity of protein fortified papaya jam was $0.49 \pm$ $0.02 \%$. This amount was higher compared to basic papaya jam $(0.18 \%)$ [17]. Sapodilla jam also having the same acidity (0.18\%) [18] In FAO standard for jam, jam normally having acidity ranged from 3.00$3.30 \%$ [8]. However the amount may vary depend on the fruit that being used for jam. For example, Black-plum jam having $0.60 \pm 0.02 \%$ [19]. 
Generally acidity not affecting the characteristic of jam. However, it affect so much in process of adding some additive to jam. In this matter, adding protein isolate to papaya jam affecting the acidity of jam.

Soy bean protein isolate fortified papaya jam had $\mathrm{pH}$ of $3.27 \pm 0.52$. FAO standardized that good jam must have $\mathrm{pH}$ with range 3.00-3.30 [16]. However $\mathrm{pH}$ of jam also affected by the fruit source of the jam. Pasion fruit jam have $\mathrm{pH}$ 2.60-3.00 and lime jam have 2.70-2.90. Basic papaya jam having $\mathrm{pH} 3.30$ [20]. Compared to jam made from other fruit, blackplum fruit jam having $\mathrm{pH} 3.42 \pm 0.07$ [19], while $\mathrm{pH}$ of jam from melon was $4.01 \pm 0.01$ [21]. $\mathrm{pH}$ affect in taste and texture by mean of astringency. In most case $\mathrm{pH}$ also represent the Vitamin $\mathrm{C}$ content of jams. $\mathrm{pH}$ affect the setting of pectin into gell so the jam can set properly [22].

Total and reducing sugar of soy bean protein isolate fortified papaya jam was $53.60 \pm 0.18$ and $33.60 \pm$ 0.78 respectively. Sugar content in jam represent the amount of sugar added and sugar content of fruit that being used as material in jam. In jam, sugar not just affect the taste but also the texture and appearance of jam. Jam that content higher amount of reducing sugar have higher shiny aspect, lesser crystallization level during storage, more stable level of sweetness, and, less exudation. Total sugar in basic papaya jam was 55.00. Total sugar and reducing sugar in melon jam was $56.18 \pm 0.66$ and $26.89 \pm 0.21$ respectively[4], while the reducing sugar amount of in black-plum fruit jam was $24.22 \pm 0.08$ [19].

Ascorbic acid, total carotenoid, and total phenol content of protein fortified papaya jam was $31.30 \pm$ $0.10,2.81 \pm 0.08$, and $0.54 \pm 0.02 \mathrm{mg} / 100 \mathrm{~g}$ respectively. The vitamin $\mathrm{C}$ content of basic papaya jam was $1.2 \mathrm{mg} / 100 \mathrm{~g}$ [21]. Ascorbic acid content in black-plum fuit jam was $33.35 \pm 0.21 \mathrm{mg} / 100 \mathrm{~g}$ [19] while in melon jam the vitamin $\mathrm{C}$ content was $5.4 \pm$ $0.06 \mathrm{mg} / 100 \mathrm{~g}$ [21]. Protein fortification of papaya jam may reduce the amount of vitamin $C$ in jam, but that's not happening in 5\% fortification papaya jam using soy protein isolate. Total phenol amount may vary depend on the fruit that being used for jam material. Total phenol represent polyphenol content in food material. The number was being affected by the amount of polyphenol compound found in fruit such as carotenoids, anthocyanins, betaalanins, etc [8]. Total phenol amount of persimmon and red beet jam was $276.70 \pm 0.08$ and $929.40 \pm 0.03 \mathrm{mg}$ GA/100g DW[20]. Total carotenoid amount in papaya chutney was $2.85 \mathrm{mg} / 100 \mathrm{~g}$ [23].
Crude protein of papaya jam fortified with soy protein isolate as much as $5 \%$ of part of the pulp was $5.43 \pm 0.06(\% \mathrm{dwb})$. The protein content in jams was very low. The lowest was grape jam, having crude protein content around $0.27 \pm 0.08 \%$, while the highest was apricot jam, which was $0.43 \pm 0.04$ $\%$ [18]. Papaya jam fortified with $2 \%$ beet root powder, $3 \%$ de-oiled soya meal, $10 \%$ milk powder, and $10 \%$ water melon powder having crude protein content of papaya jam was $5.77 \pm 0.20 \%$ [8] Fortifying jam and fruit product with protein have been a challenge for food technicians and scientists for long since the amphoteric characteristics of protein may affect the solubility of the protein in jams or other fruit product which most of it have high acidity. That's why very less fruit product enriched with protein can be found largely in market. The crude protein content in unripe papaya pulp was $1.46 \%$, while in the ripe papaya pulp, the crude protein content was $0.29 \%$ [24]. From the result we can conclude papaya jam incorporated with soy protein isolate with ration of $5 \%$ having much higher protein content compared to the unprocessed one.

Table. 1. Physico-chemical characteristic of protein fortified papaya jam

\begin{tabular}{ll} 
Parameters & $\begin{array}{l}\text { Fortified } \\
\text { papaya jam }\end{array}$ \\
Moisture Contents (\%) & $31.07 \pm 0.20$ \\
Total Soluble Solid (TSS) $(\%)$ & $68.00 \pm 0.54$ \\
Acidity (\%) & $0.49 \pm 0.02$ \\
Ph & $3.27 \pm 0.52$ \\
Total Sugar (\%) & $53.60 \pm 0.18$ \\
Reducing Sugar (\%) & $33.60 \pm 0.78$ \\
$\begin{array}{l}\text { Ascorbic Acid Content } \\
\text { (mg/100g) }\end{array}$ \\
$\begin{array}{l}\text { Total Carotenoid (mg/100g) } \\
\text { Total Phenol (mg/100g) }\end{array}$ \\
Crude protein $(\% \mathrm{dwb})$ \\
\hline
\end{tabular}

\section{CONCLUSION}

Papaya jam fortified with soy protein isolate with ratio of $5 \%$ had $31.07 \pm 0.20 \%$ moisture contents, $68.00 \pm 0.54 \%$ Total Soluble Solid, $0.49 \pm 0.02 \%$ of acidity, $3.27 \pm 0.52 \mathrm{in} \mathrm{pH}, 31.30 \pm 0.10 \mathrm{mg} / 100 \mathrm{~g}$ ascorbic acid content, $53.60 \pm 0.18 \%$ total sugar amount, $33.60 \pm 0.78 \%$ reducing sugar, $2.81 \pm 0.08$ $\mathrm{mg} / 100$ total carotenoid, $0.540 .54 \pm 0.02 \mathrm{mg} / 100 \mathrm{~g}$ total phenol, and $5.43 \pm 0.06 \%$ dwb of crude protein content. The physico-chemical of protein fortified papaya jam was still in the range of physicochemical of jam standardize by FAO and results of 
physico-chemical analysis of jams with papaya and other fruits as the material. Protein fortified papaya jam had much higher protein amount compared to other basic jams.

\section{REFFERENCE}

[1] I. A, "Relationship between energy and protein intake with body mass index and mid upper arm circumference (muac) preconception women in Ujung Tanah and Biringkanaya subdistrict Makasar [Udergraduate Thesis\}," Universitas Hasanudin, Makassar, 2013.

[2] J. R. Hoffman and M. J. Falvo, "Protein wich is best," Journal of Sport Science and Medicine, vol. 3, no. 3, pp. 118-130, 2004.

[3] A. Luximon-Ramma, T. Bahorun and A. Crozier, "Antioxidant actions and phenolic and vitamin $\mathrm{C}$ contents of common Mauritian exotics fruits," Journal of the science of food and agriculture, vol. 83, pp. 496-502, 2003.

[4] V. T. A. Y. Bosra, "Papaya an innovative raw material for food and pharmaceutical processing industry," Journal of Pharmacy and Biological Science, vol. 4, no. 1, pp. 6875, 2013.

[5] T. Oksuz, E. Surek, Z. Tacer-Caba and D. Nilufer-Erdil, "Phenolic contents and antioxidant activities of persimmon and red beet jams produced by source impregnations Food Science and Technology," vol. 3, no. 1, pp. 1-8, 2015.

[6] N. V. Phong, "Studies on the use of soybean and anola to improve the nutritional quality of guava (Psidium gujava L) jam [Master Thesis]," Center of Food Science and Technology, CSS Haryana Agricultural University, Hisar, India, 2004.

[7] K. Shimada, K. Fujikawa, K. Yahara and T. Nakamura, "Antioxidative properties of xanthone on the auto oxidation of soybean in cylcodextrin emulsion," Journal of Agriculture Food and Chemistry, vol. 40, pp. 945-948, 1992.

[8] A. Doke, A. Arya, J. Bhaleroa and R. S. Shinde, "Development of value added papaya and pineapple jams," Food Science Research Journal, vol. 8, no. 1, pp. 76-82, 2017.

[9] B. Anju, K. Kumari, V. Anand and M. Anjum, "Preparation, quality, evaluation, and storage stability of peach-soy fruit leather," Journal of Agriculture, vol. 12, no. 1, pp. 73-88, 2014.
[10] A. Khan, S. Ali, K. -ur-Rehman, S. Manzoor, S. R. Ayub and M. Ilyas, 2016. [Online]. Available: https://doi.org/10.7287/peerj.preprints.1777v 1. [Accessed 6 August 2018].

[11] S. Rajarathnam, "Perspectives of processing papaya (Carica papaya) fruit national and international strategies.," Acta Horticulture, vol. 851, pp. 547-554, 2010.

[12] AOAC, "Official Methods of Analysis (18 th Ed)," Association of Official Analytical Chemists , Virgina, U.S.A, 2005.

[13] Rodriguez-Amaya and D. B, A Guide to Carotenoids Analysis in Foods., Washington DC: ILSI Press, 1999.

[14] S. Ranganna, Handbook of Analysis and Quality Control for Fruit and Vegetable Products. 2 end, New Delhi, India: Tata McGraw-Hill Publishing Co. Ltd, 2003.

[15] M. N. Mohd Naeem, M. N. Mohd Fairulniz, M. Norhayati and e. all, "The nutritional composition of fruit jams in the MAlaysian Market," Journal of the Saudi Society of Agricultural Sciences , vol. 3, no. 2, pp. 9-15, 2015.

[16] Food and Agriculture (FAO), "Standard for Jam, Jelies , and Marmalade," FAO, 2017. [Online]. Available: http://www.fao.org/faowho-codexalimentarius/shproxy/it/?Ink=1\&url=https $\% 253 \mathrm{~A} \% 252 \mathrm{~F} \% 2$ 52Fworkspace.fao.org\%252252Fsites $\% 252$ codex $\% 252$ FStandards\%252FCODEX $\% 2 \mathrm{BSTAN} \% 2 \mathrm{~B} 296-$

2009\%252FCXS_296E.pdf. [Accessed 6 agustus 2018].

[17] Codex, "Codex General standard for jam, jelies, a," CODEX STAN 296 1989, 2015.

[18] Karanjalker, G. R, D. B. Singh and V. B. Rajwade, "Development and Evaluation of Protein enriched guava nectarbelended with soymilk.," the Bioscan, vol. 8, no. 2, pp. 631634, 2013.

[19] S. O. a. A. J. Ajenifujah-solebo, "Physicochemical properties and sensory evaluations of jam made from black-pulm fruit (Vitex doniana)," African Journal of Food , Agriculture Nutrition and Development, vol. 12, no. 3, 2011.

[20] M. S. Mahomud, K. M. Pervin and N. e. a. Gupta, "Processing and preservation of papaya jam," Journal of Science and Technology, vol. 6, pp. 37-41, 2008.

[21] F. Benmeziane and L. e. a. DjermouneArkoub, "Physicochemical characteristic and phytochemical content of jam made from 
melon (Cucumis Melo)," International Food Research Journal, vol. 25, no. 1, pp. 68-75, 2013.

[22] The Schumacer Center, Pratical Actions: Technology Challenging Proverty, Pratical Brief for Jams, Jellies and Marmalade, Warwicke, UK: Bouton on Dunsmore, 2015.

[23] Sachin, R. Gehlot and S. e. a. Shiddiqui, "Changes in chemical constituents and overall acceptability of Aonla-Papaya jam and cutney during sorage," International Journal of Currents Microbiology and Applied Sciences , vol. 7, no. 3, pp. 2001-2007, 2018.
[24] K. S. Chuckwuka and M. a. U. U. N. Iwuagwu, "Evaluations of Nutritional Components (Carica Papaya, L at differents stages of ripening," Journal of Pharmacy and Biological Science, vol. 6, no. 4, pp. 13-16, 2013. 